\title{
Percutaneous Sclerotherapy with Aethoxysklerol in the Treatment of Simple Renal Cyst: A Five-Year Experience of a Single Institution
}

\section{Basit Böbrek Kisti Tedavisinde Aethoxysclerol Perkütan Skleroterapisi: Beş Yıllık Tek Merkez Deneyimi}

\author{
Tarık Yonguç, Volkan Şen, Tansu Değirmenci, İbrahim Halil Bozkurt, Serkan Yarımoğlu, \\ Zafer Kozacıoğlu, Özgü Aydoğdu, Bülent Günlüsoy
}

Izmir Bozyaka Training and Research Hospital, Clinic of Urology, Izmir, Turkey

\section{What's known on the subject? and What does the study add?}

Symptomatic renal cysts can be managed by a variety of surgical and percutaneous methods. Percutaneous sclerotherapy is more widely used compared to the other treatment methods, because of less pain, less bleeding and shorter hospitalization time. Sclerotherapy using aethoxysclerol is a reliable, cost-effective, minimally invasive and effective method for the treatment of simple renal cysts. However, this method could not reach the desired level of success in the treatment of upper pole renal cysts. In the management of upper pole renal cysts, different sclerosing agents or other treatment options, such as laparoscopic cyst excision should be taken into consideration.

\section{ABSTRACT}

Objective

To evaluate the efficacy and safety of sclerotherapy using aethoxysklerol in the outpatient treatment of simple renal cysts.

\section{Materials and Methods}

Between 2008 and 2013, 86 symptomatic patients (44 men, 42 women) with 89 simple renal cysts with a diameter larger than $5 \mathrm{~cm}$ on ultrasonography (US) or computed tomography were documented in the study. Initial cyst puncture was done with an $18 \mathrm{G}$ needle under US guidance with the patient in the prone position. At the end of the aspiration, $2 \mathrm{ml}$ of 1\% aethoxysklerol was injected into the cystic cavity per $100 \mathrm{ml}$ of cystic fluid aspirated. Success rate was evaluated as complete or partial; $>90 \%$ reduction or $50-90 \%$ reduction in cyst size, respectively. Failure was defined as $<50 \%$ reduction in cyst size.

\section{Results}

The rate of complete success was $45 \%$, partial success $20.2 \%$, and failure was $34.8 \%$. When we compared the success rate of aethoxysklerol sclerotherapy according to cyst localization and size, we observed that the success rates in lower pole cysts measuring $>10 \mathrm{~cm}$ and between 7.5$10 \mathrm{~cm}$ in diameter were significantly higher than that in upper pole cysts in same sizes ( $p=0.009$ and $p=0.018$, respectively). When the success rate
ÖZ

Amaç

Semptomatik böbrek kistlerinin tedavisinde aethoxysclerol skleroterapisinin etkinliğini ve güvenilirliğini değerlendirmektir.

\section{Gereç ve Yöntem}

2008-2013 yılları arasında ultrasonografi ya da bilgisayarlı tomografi ile tanısı konulan, semptomatik ve $5 \mathrm{~cm}$ 'den büyük böbrek kisti nedeni ile perkütan skleroterapi uygulanan 86 hasta ve toplamda 89 böbrek kisti retrospektif olarak dökümente edildi ve çalışmaya dahil edildi. İlk kist ponksiyonu yüzüstü pozisyonda ultrasonografi eşliğinde $18 \mathrm{G}$ iğne ile yapıldı. Aspirasyon sonunda, aspire edilen her $100 \mathrm{ml}$ aspirat için $2 \mathrm{ml} \% 1$ aethoxysclerol kistik kaviteye enjekte edildi. Kist büyüklüklerinde \%50-90 küçülme parsiyel başarı olarak nitelendirilirken, >\%90 küçülme tam başarı olarak değerlendirildi. Başarısızlık kist boyutunda \%50'den az küçülme olarak tanımlandı.

Bulgular

Başarı oranları tam ve parsiyel olarak sırasıyla \%45 ve \%20,2 iken, başarısızlık oranı \%34,8 idi. Aethoxysclerol skleroterapisi başarı oranlarını kist büyüklükleri ve lokalizasyonlarına göre karşılaştırdığımızda; $>10 \mathrm{~cm}$ ve 7,5-10 cm alt pol kistlerindeki başarı oranları, aynı büyüklükteki üst pol kistlerindeki başarı oranlarına göre anlamlı derecede daha yüksekti

\section{Correspondence}

Volkan Şen MD, İzmir Bozyaka Training and Research Hospital, Clinic of Urology, İzmir, Turkey

Phone: +90 5533896859 E-mail: sen_volkan@yahoo.com Received: 11.08.2015 Accepted: 02.11.2015

Results of our study were presented in 34th Congress of the Société Internationale D'Urologie which was held in Glasgow on 12-15, October 2014 as a poster presentation 'Simple renal cyst sclerotherapy with aethoxysklerol: A 5-year experience of a single institution' 


\section{ABSTRACT}

of sclerotherapy was assessed according to the cyst sizes, the success rates and cyst sizes were inversely proportional $(p=0.01)$.

\section{Conclusion}

Sclerotherapy with aethoxysklerol is a reliable, cost-effective, minimally invasive, and effective method for the treatment of simple renal cysts.

\section{Keywords}

Aethoxysclerol, minimally invasive, renal cyst, percutaneous sclerotherapy, ultrasound-guided

\section{ÖZ}

(sırasıyla $p=0,009$ ve $p=0,018$ ). Kist büyüklüklerine göre skleroterapi başarısı değerlendirildiğinde ise kist boyutları ve başarı oranları ters orantılı olarak saptandı.

\section{Sonuç}

Aethoxysclerol skleroterapisi semptomatik böbrek kistlerinin tedavisinde güvenilir, düşük maliyetli ve etkin bir tedavi yöntemidir; ancak üst pol böbrek kistlerinin tedavisinde henüz istenilen başarı oranlarına ulaşamamıştır. Üst pol böbrek kistlerinin tedavisinde laparoskopik kist eksizyonu gibi diğer tedavi seçenekleri göz önünde bulundurulmalıdır.

\section{Anahtar Kelimeler}

Aethoxysklerol, minimal invaziv, böbrek kisti, perkütan skleroterapi, ultrasonografi eşliğinde

\section{Introduction}

Simple renal cysts are common and usually asymptomatic in adults (1) and, the frequency of the condition increases with age, with an incidence of 50\% in autopsied patients over 50 years of age (2). Although most simple renal cysts are asymptomatic, some patients may experience symptoms and signs as flank pain, hematuria, cyst rupture, hemoperitoneum or hypertension (3). Symptomatic renal cysts can be managed by a variety of surgical and percutaneous methods, including percutaneous aspiration (with or without injection of a sclerosing agent), endoscopic marsupialization or excision, open surgery and laparoscopic cyst excision $(4,5)$. Percutaneous sclerotherapy is more widely used compared to the other treatment methods, because of less pain, less bleeding and shorter hospitalization time (6). The procedure can also be performed on a outpatient basis. This method is also found to be reliable, easy to apply and very cost-effective (7). The sclerosing agents used for percutaneous sclerotherapy are bismuth phosphate, minocycline, ethanolamine oleate, povidone iodine, ethanol, and acetic acid $(8,9,10,11,12,13,14)$. Some factors are important when selecting the most effective agent with the least systemic and local complications, availability and cost effectiveness. Aethoxysklerol has been shown to be an effective and safe sclerosing agent in the treatment of varicose veins and hemorrhoids (15). In this study, we evaluated the efficacy and safety of percutaneous sclerotherapy using aethoxysklerol in the treatment of simple renal cysts in a 5 -year period.

\section{Material and Methods}

Between 2008 and 2013, 86 symptomatic patients (44 men, 42 women) with 89 Bosniak type- 1 renal cysts with a diameter larger than $5 \mathrm{~cm}$ on ultrasonography (US) or computed tomography (CT) were treated by US-guided percutaneous aspiration and injection of aethoxysklerol solution. The study protocol was approved by the Local Ethics Committee. The volume (V) of each cyst was calculated as $V=d 3 / 6(d=$ diameter of the cyst for a spherical lesion and $d=(\mid x w \times d) / 3$ for a nonspherical lesion; I, w and $d$ mean as length, width and depth of the cyst, respectively (16). All cysts were initially evaluated with US and if there was a suspicion of communication with the collecting system, contrast-enhanced CT or intravenous pyelography (IVP) was performed. Initial cyst puncture was done by an $18 \mathrm{G}$ needle under US guidance with the patient in the prone position under local anesthesia with lidocaine (Figure 1, 2). The first $10 \mathrm{ml}$ of aspirate was taken for cytological and biochemical examination. In addition, a $2 \mathrm{ml}$ sample of the fluid aspirated from the cyst was mixed with 2 $\mathrm{ml}$ of 95\% ethanol. The sample was considered positive for protein if precipitation was immediately observed; otherwise, the sample was considered negative. Patients whose aspirate was negative for protein were not subjected to sclerotherapy as this might indicate that the cyst communicated with the collecting system. At the end of the aspiration, $2 \mathrm{ml}$ of 1\% aethoxysklerol was injected into the cystic cavity per $100 \mathrm{ml}$ of cystic fluid aspirated. The patient was held in the supine, prone, and lateral decubitus positions for 5 minutes each to increase the contact between the surface of the cyst and the sclerosing agent. No attempt was made to aspirate or drain the sclerosing agent after instillation. The patients were observed in outpatient setting until the first urination with clear urine and were evaluated at $3^{\text {rd }}$ month after procedure and annually afterwards. The pre-operative and post-operative US findings were documented to compare the cyst recurrence and the reduction in cyst size. Success was defined as complete or partial; as $>90 \%$ reduction or $50-90 \%$ reduction in cyst size, respectively. Failure was defined as $<50 \%$ reduction in cyst size.

\section{Statistical Analysis}

The statistical software package SPSS version 20.0 (SPSS Inc, Chicago, IL, USA) was employed for data management and analysis. Chi-square test and Fisher's exact test were performed. Significance was set at $p \leq 0.05$.

\section{Results}

The mean age of the subjects was 67.2 years (range 42-82). The median follow-up period was 36 months (range 12-76). Patients' characteristics and the locations of the cysts are summarized in Table 1. The mean cyst size and $V$ before sclerotherapy were $8.3 \mathrm{~cm}$ (range $=5-14)$ and $240 \mathrm{ml}$ (range $=60-1370$ ), respectively. The mean $\mathrm{V}$ of the aspirated cyst fluid was $220 \mathrm{ml}$ (range $=40-1150 \mathrm{ml}$ ). The cytologic examination was negative for neoplastic cells in all patients, and biochemical analysis was similar to the plasma. The complete and 
partial success rates were $45 \%$ and $20.2 \%$, respectively and the failure rate was $34.8 \%$. The success rates were $48.7 \%, 62.5 \%$ and $85.3 \%$ in cysts located on the upper, middle and lower poles, respectively (Table 2). Minor complications, such as nausea, pain and microscopic hematuria were observed in 8 patients (8.9\%). All the complications were classified as grade 1 according to the Clavian-Dindo classification. No major complications, such as perirenal hemorrhage, pneumothorax, arteriovenous fistula or urinoma formation were observed. When we compared the success of sclerotherapy with aethoxysklerol according to the cyst localization and sizes, the success rate in lower pole cysts in $>10 \mathrm{~cm}$ was significantly higher than in upper pole cysts $>10 \mathrm{~cm}$ $(p=0.009)$. In addition, the success rate in lower pole cysts measuring $7.5-10 \mathrm{~cm}$ was significantly higher than in upper pole cysts measuring $7.5-10 \mathrm{~cm}$ in diameter $(p=0.018)$. However, the difference between the success rates was not significant in cysts measuring $5-7.5 \mathrm{~cm}$ $(p=0.502)$. When we compare the success of sclerotherapy according to the cyst sizes in the upper, middle and lower poles, the difference was not significant ( $p>0.05)$. The success of sclerotherapy increased

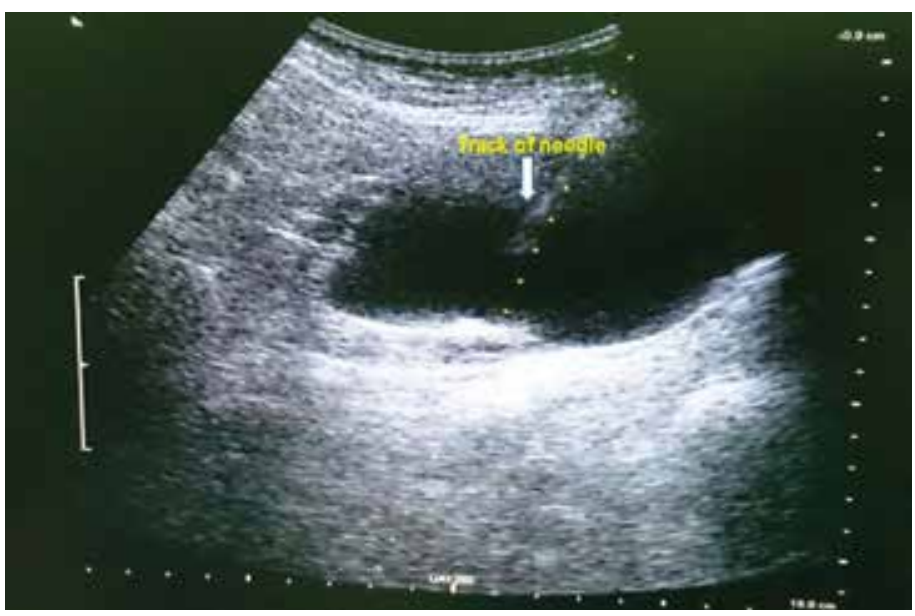

Figure 1. Ultrasound-guided needle aspiration of a simple renal cyst. The needle can be seen inside the cyst

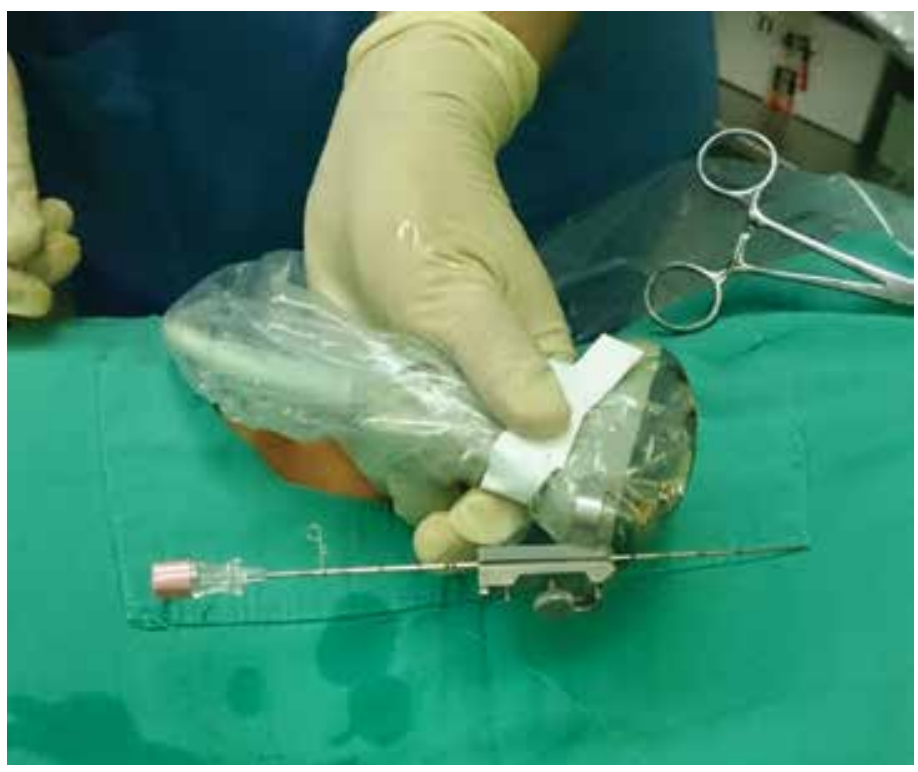

Figure 2. Ultrasound-guided needle aspiration system when the cyst size decreased $(p=0.01)$. However, this relationship was not detected in lower and middle pole cysts $(p=0.9$ and $p=0.587$, respectively).

\section{Discussion}

Simple renal cysts are common, usually incidentally diagnosed by US or CT (1). The etiology of renal cysts is still not known clearly. Obstruction and ischemia of the distal convoluted tubule have been postulated as a cause (17). Most simple cysts are asymptomatic and usually regular follow-up is sufficient for management. Some of them can cause symptoms, such as pain, hematuria, hypertension, recurrent infection or obstructive uropathy for which, a definitive treatment might be necessary (18). Symptomatic renal cysts can be managed by a variety of surgical and percutaneous methods, including percutaneous aspiration (with or without injection of sclerosing agent), open surgical or laparoscopic marsupialization, percutaneous endocystolysis and cyst excision (19). Surgical intervention is not preferred due to the risk of morbidity and mortality especially in elderly patients (20). The advantages of percutaneous drainage of simple renal cysts are; minimally invasiveness, well tolerability, easy administration under US guidance and no necessity for hospitalization (11). However, simple aspiration without sclerosing agents is associated with a recurrence rate of 30-78\% (10). Various sclerosing agents have been used to improve the efficacy of percutaneous drainage. In this wise, the combination of drainage and sclerotherapy reduces the rate of recurrence (10).

The sclerosing agents for percutaneous sclerotherapy are bismuth phosphate, minocycline, ethanolamine oleate, povidone iodine, ethanol and acetic acid $(8,9,10,11,12,13,14)$. They destroy the lining epithelium of the cyst and provoke local inflammation on the luminal surface of the cyst leading to the adhesion of the walls (6). Some factors such as systemic and local complications (e.g. infection, hemorrhage), availability, and cost effectiveness are important in selecting the most effective agent. Most of the studies were done

Table 1. Characteristics of 86 cases with 89 simple renal cysts

\begin{tabular}{|l|l|}
\hline Characteristics & Number of cases (\%) \\
\hline No. of patients & 86 \\
\hline Age (years) & $67.2(42-82)$ \\
\hline Sex & \\
Male & $44(51.2 \%)$ \\
Female & $42(48.8 \%)$ \\
\hline Site & \\
Right & $45(50.5 \%)$ \\
Left & $41(46 \%)$ \\
Both & $3(3.4 \%)$ \\
\hline Location & \\
Upper & $39(43.8 \%)$ \\
Middle & $16(18 \%)$ \\
Lower & $34(38.2 \%)$ \\
\hline Size & \\
$5-7.5 \mathrm{~cm}$ & $29(32.6 \%)$ \\
$7.5-10 \mathrm{~cm}$ & $42(47.2 \%)$ \\
$>10 \mathrm{~cm}$ & $18(20.2 \%)$ \\
\hline Mean size $(\mathrm{cm})$ & $8.3(5-14)$ \\
\hline Mean volume $(\mathrm{ml})$ & $240(60-1370)$ \\
\hline &
\end{tabular}


Table 2. Success ratio of the cysts

\begin{tabular}{|c|c|c|c|c|c|}
\hline & Total & $>90 \%$ reduction & $50-90 \%$ reduction & $<50 \%$ reduction & Success \\
\hline Upper pole & $39(43.8 \%)$ & 14 & 5 & 20 & $48.7 \%$ \\
\hline$>10 \mathrm{~cm}$ & 9 & 0 & 1 & 8 & $11 \%$ \\
\hline $7.5-10 \mathrm{~cm}$ & 17 & 5 & 3 & 9 & $47 \%$ \\
\hline \multirow{2}{*}{$5-7.5 \mathrm{~cm}$} & 13 & 9 & 1 & 3 & $76.9 \%$ \\
\hline & & & & & $p=0.01^{*}$ \\
\hline Middle pole & $16(18 \%)$ & 5 & 5 & 6 & $62.5 \%$ \\
\hline$>10 \mathrm{~cm}$ & 2 & 0 & 1 & 1 & $50 \%$ \\
\hline $7.5-10 \mathrm{~cm}$ & 6 & 1 & 2 & 3 & $50 \%$ \\
\hline \multirow[t]{2}{*}{$5-7.5 \mathrm{~cm}$} & 8 & 4 & 2 & 2 & $75 \%$ \\
\hline & & & & & $p=0.587^{*}$ \\
\hline Lower pole & $34(38.2 \%)$ & 21 & 8 & 5 & $85.3 \%$ \\
\hline$>10 \mathrm{~cm}$ & 7 & 3 & 3 & 1 & $85.7 \%$ \\
\hline $7.5-10 \mathrm{~cm}$ & 19 & 12 & 4 & 3 & $84.2 \%$ \\
\hline \multirow[t]{2}{*}{$5-7.5 \mathrm{~cm}$} & 8 & 6 & 1 & 1 & $87.5 \%$ \\
\hline & & & & & $p=0.975^{*}$ \\
\hline Total & 89 & $40(45 \%)$ & $18(20.2 \%)$ & $31(34.8 \%)$ & $65.2 \%$ \\
\hline
\end{tabular}

with ethanol injection and it was found to be more effective than only percutaneous drainage in renal cysts $(3,6,18)$. However, with the leakage of phenol or ethanol into the surrounding tissue, minor complications such as local tissue corrosion and major complications such as aseptic abscesses and severe central nervous system depression are possible (6). Because of these complications, insertion of a pig-tail catheter into the cyst and ethanol aspiration from the renal cyst after instillation was recommended but this is controversial (10). The agent we have used, aethoxysklerol, is a safe molecule which does not cause major complications and aspiration after instillation is not necessary.

Aethoxysklerol is a sclerosing agent which has been used for the treatment of varicose veins, venous malformations and lymphoceles (15). Polidocanol is the active form of aethoxysklerol and it consists of 95\% hydroxypolyethoxydodecane and 5\% ethyl alcohol as a preservative (21). It poses a detergent action that produces a rapid overhydration of the cells, with consequent destruction. Small V of substance is enough for its sclerosing effect, thus, its use is easier than that for ethanol. Because of its well-known safety profile from the venous applications, it may be used without aspiration and can be left in the cystic cavity to destroy the lining epithelium (21). Due to the painless application, no intracystic anesthesia or sedation is required.

To the best of our knowledge, there are only nine reports of sclerotherapy with aethoxysklerol for simple renal cysts $(22,23,24,25,26,27,28,29,30)$. Our study has the second largest number of patients in the literature. The pigtail catheter was used in most of them and the patients were hospitalized for one day. In our study; the sclerosing agent, aethoxysklerol, was used without aspiration and to perform the procedure in an outpatient setting, we did not use a pigtail catheter for drainage. Thus, the method became more costeffective and more tolerable for the patients. Minor complications, such as hematuria, nausea and pain were observed in 8 patients and no major complication was seen as in the previous reports.

A significant correlation was found between size and location of the cyst and success of percutaneus scleroherapy in a study by elDiasty et al. (18). Our results confirm these data with success rate of $85.3 \%$ and $48.7 \%$ for the lower pole and the upper pole cysts, respectively $(p<0.05)$. Our success rates decreased with the growth of cysts sizes (Table 2). These low rates in the upper pole may be due to the difficulties of the procedure in the upper pole.

Sclerotherapy using aethoxysklerol is a reliable, cost-effective, minimally invasive and effective method for the treatment of simple renal cysts. However, this method could not reach the desired level of success in the treatment of upper pole renal cysts. In the management of upper pole renal cysts, different sclerosing agents or other treatment options, such as laparoscopic cyst excision should be taken into consideration.

\section{Authorship Contributions}

Ethics Committee Approval: The study was approved by the Local Ethics Committee of Izmir Training and Research Hospital, Informed Consent: Consent form was filled out by all participants, Concept: Tarık Yonguç, Volkan Şen, Ibrahim Halil Bozkurt, Design: Tarık Yonguç, Özgü Aydoğdu, Tansu Değirmenci, Zafer Kozacıoğlu, Data Collection or Processing: Serkan Yarımoğlu, Zafer Kozacıoğlu, Analysis or Interpretation: Özgü Aydoğdu, Tansu Değirmenci, Literature Search: Tarık Yonguç, Bülent Günlüsoy, Volkan Şen, Ibrahim Halil Bozkurt, Writing: Tarık Yonguç, Volkan Şen, Bülent Günlüsoy, Peer-review: Internal peer-reviewed, Conflict of Interest: No conflict of interest was declared by the authors, Financial Disclosure: The authors declared that this study has received no financial support. 


\section{References}

1. Laucks SP Jr, Mc Lachlan MS. Aging and simple cysts of the kidney. Br J Radiol 1981;54:12-14.

2. Yoo KH, Lee SJ, Jeon $\mathrm{SH}$. Simple renal cyst sclerotherapy with acetic acid: our 10-year experience. J Endourol 2008;22:2559-2563.

3. De Dominicis $C$, Ciccariello $M$, Peris F, DiCrosta G, Sciobica F, Zuccalà A, lori F. Percutaneous sclerotization of simple renal cysts with $95 \%$ ethanol followed by $24-48 \mathrm{~h}$ drainage with nephrostomy tube. Urol Int 2001;66:18-21.

4. Amar $A D$, Das $S$. Surgical management of benign renal cysts causing obstruction of renal pelvis. Urology 1984;24:429-433.

5. Okeke AA, Mitchelmore AE, Keeley FX, Timoney AG. A comparison of aspiration and sclerotherapy with laparoscopic de-roofing in the management of symptomatic simple renal cysts. BJU Int 2003;92:610613.

6. Brown B, Sharifi R, Lee M. Ethanolamine sclerotherapy of a renal cyst. J Urol 1995;153:385-386.

7. Consonni $P$, Nava L, Scattoni $V$, Bianchi A, Spaliviero M, Guazzoni G, Bellinzoni P, Bocciardi A, Rigatti P. Percutaneous echo-guided drainage and sclerotherapy of symptomatic renal cysts: critical comparison with laparoscopic treatment. Arch Ital Urol Androl 1996;68:27-30.

8. Holmberg G, Hietala SO. Treatment of simple renal cysts by percutaneous puncture and instillation of bismuth-phosphate. Scand J Urol Nephrol 1989;23:207-212.

9. Seo TS, Oh JH, Yoon Y, Lim JW, Park SJ, Chang JG, Jeon YH. Acetic acid as a sclerosing agent for renal cysts: comparison with ethanol in follow-up results. Cardiovasc Intervent Radiol 2000;23:177-181.

10. Hanna RM, Dahniya MH. Aspiration and sclerotherapy of symptomatic simple renal cysts: value of two injections of a sclerosing agents. AJR Am J Roentgenol 1996;167:781-783.

11. Fontana D, Porpiglia F, Morra I, Destefanis P. Treatment of simple renal cysts by percutaneous drainage with three repeated alcohol injections. Urology 1999;53:904-907.

12. Dalton $D$, Neiman $H$, Grayhack JT. The natural history of simple renal cysts: a preliminary study. J Urol 1986;135:905-908.

13. Ohkawa M, Tokunaga S, Orito M, Shimamura M, Hirano S, Okasho A, Kosaka S. Percutaneous injection sclerotherapy with minocycline hydrochloride for simple renal cysts. Int Urol Nephrol 1993;25:37-43.

14. Phelan M, Zajko A, Hrebinko RL. Preliminary results of percutaneous treatment of renal cysts with povidone-iodine sclerosis. Urology 1999;53:816-817.
15. Jain R, Bandhu S, Sawhney $S$, Mittal R. Sonographically guided percutaneous sclerosis using 1\% polidocanol in the treatment of vascular malformations. J Clin Ultrasound 2002;30:416-423.

16. Terada N, Ichioka K, Matsuta Y, Okubo K, Yoshimura K, Arai Y. The natural history of simple renal cysts. J Urol 2002;67:21-23.

17. Cho DS, Ahn HS, Kim SI, Kim YS, Kim SJ, Jeon GS, Won JH. Sclerotherapy of renal cysts using acetic acid: a comparison with ethanol sclerotherapy. Br J Radiol 2008;81:946-949.

18. el-Diasty TA, Shokeir AA, Tawfeek HA, Mahmoud NA, Nabeeh A, Ghoneim MA. Ethanol sclerotherapy for symptomatic simple renal cysts. J Endourol 1995;9:273-276.

19. Busato WF Jr, Bettega LB. Percutaneous endocystolysis, a safe and minimally invasive treatment for renal cysts: a 13-year experience. J Endourol 2010;24:1405-1410.

20. Kropp KA, Grayhack JT, Wendel RM Dahl DS. Morbidity and mortality of renal exploration for cyst. Surg Gynecol Obstet 1967;125:803-806.

21. Goktay AY, Secil M, Ozcan MA, Dicle 0. Percutaneous treatment of congenital splenic cysts: drainage and sclerotherapy with polidocanol. Cardiovasc Intervent Radiol 2006;29:469-472.

22. Reuter HJ. Drug sclerosing of kidney cysts. Z Urol Nephrol 1986;79:503-509.

23. Zellweger $U$, Meyenberger $C$, Bühler $H_{1}$ Ammann R. Ultrasonically-guided sclerosing of kidney and liver cysts using polidocanol. Schweiz Rundsch Med Prax 1990;79:1412-1415.

24. Trombetta C, Salisci E, Deriu M, Savoca G, Sanna M, Paoni A. Role of echography in the diagnostic-therapeutic management of renal cysts. Arch Ital Urol Androl 1994;66:145-150.

25. Ohta S, Fujishiro Y, Fuse H. Polidocanol sclerotherapy for simple renal cysts. Urol Int 1997;58:145-147.

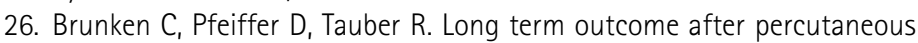
sclerotherapy of renal cysts with polidocanol. Urologe A 2002;41:263266.

27. Agostini S, Dedola GL, Gabbrielli S, Scelzi S, Dattolo E, Muzzillo F, Masi A. Percutaneous treatment of simple renal cysts with sclerotherapy and extended drainage. Radiol Med 2004;108:522-529.

28. Ormeci $N$, Idilman $R$, Tüzün $A$, Erdem $H$, Palabiyikoğlu $M$. A new percutaneous approach for the treatment of hydatid cyst of the kidney: long-term follow-up. Int Urol Nephrol 2005;37:461-464.

29. Agarwal $M$, Agrawal MS, Mittal $R$, Sachan V.A randomized study of aspiration and sclerotherapy versus laparoscopic deroofing in management of symptomatic simple renal cysts. J Endourol 2012;26:561-565.

30. Reuter $\mathrm{HJ}$, Ottinger $\mathrm{H}$. Obliteration of renal cysts and polycystic kidneys. Arch Esp Urol 1987;40:314-318. 